\title{
The Boundary-spanning Role of Democratic Learning Communities
}

Implementing the IDEALS

\section{Leslie Williams, Jean Cate and Mary John O'Hair}

\begin{abstract}
A B S T RAC T
This multi-case study investigates characteristics and practices in schools that expand the traditional boundaries of school leadership and transform schools into democratic learning communities based on the level of implementation of the IDEALS framework. This investigation serves as a modus to illuminate democratic processes that change schools and address the needs of the students, not the needs of the adults in the system. A sample of five purposefully selected high schools, from the Midwest USA, was utilized. The schools serve Grade 9-12 students, but vary in size, residential area and socioeconomic status of the students. This study illuminates some of the challenges and strategies that facilitate or impede the process of creating more democratic schools that expand the boundaries of inquiry and discourse to include a broader range of community stakeholders and that respect and embrace issues of equity.
\end{abstract}

KEY W O R S collaboration, democratic learning communities, high schools, school change, teacher leadership, teacher learning

\section{Introduction}

Today's traditional school structures are characterized as bureaucracies arranged into hierarchies with top-down leadership, isolating teachers and creating a culture that negatively impacts educational quality and systemic school change. Yet, John Dewey (1916) posits that democratic societies provide open participation focused on the common good and schools that function as democratic societies display differing aims and methods from those that do not. In fact, some establish barriers to the practices of open participation for the common good. Furman and Shields (2003) argue that democracy is less about acceptance of individual rights and majority rule and more about mutual understanding and interdependence focused on actions for the common good. In fact, they warn that weak democratic practices can perpetuate the status quo and 
marginalization of minority groups. They further argue the interdependency of democratic community and social justice as transformative ideals. Green (1999) proposes that a democratic ideal can guide and temper the development of a community in which diversity and reflective inquiry are respected and encouraged.

A school should be a place in which teachers and students learn the art of living together as citizens' (Meier, 2002: 176) and should 'promote individual growth and participation in a democratic society' (O'Hair et al., 2000: 6). Collaborative inquiry and discourse are important factors in sustaining the effort to create a professional learning community (PLC) and reduce this isolation, and evidence exists of improved student learning in schools with collaborative norms (Lee and Smith, 1996; Newmann and Wehlage, 1995; Schmoker, 1999; Williams et al., 2008). Apple and Beane (1995) provide case study evidence of democratic practices in public schools, while Cate et al. (2006) provide a case study of the transformation of a public elementary school from a traditional school, into a professional learning community, and ultimately to a democratic learning community.

The purpose of the study reported in this article is to investigate characteristics and practices in schools that expand the traditional boundaries of school leadership and transform schools into democratic learning communities. This study seeks answers to these questions: what are the differences between high schools that establish barriers to open participation and those that expand their boundaries? How do high schools change and become more democratic?

\section{The Framework}

The broader conviction for public education must be that of democracy which ensures quality learning and citizenship for all and must not yield to economic pressures to produce a quality workforce (Goodlad and McMannon, 1997). Glickman (1998: 8) advocates for 'democracy as education' based on the capacity for learning with and from each other and active participation in the process of teaching and learning. Changing traditional schools into communities that foster increased learning and active participation requires strong leadership from a group of committed individuals who are willing to question their practices, engage in discourse, and learn from each other. These initial stages of change within a school have been known to transform a school into a learning community (O'Hair et al., 2000). Changes in a school community move along a continuum from a traditional school to a PLC and finally to a democratic learning community (Cate, 2004; O'Hair et al., 2000) (see Figure 1).

\section{Traditional Schools}

High schools are resistant to change (Brady, 2008; Hargreaves and Goodson, 2006). Brady (2008) cites evidence of the departmentalization of high schools as a component in this resistance. McLaughlin and Talbert (2001) suggest that 
Figure 1 Steps in progressing from a traditional schooling to a learning community to a democratic community

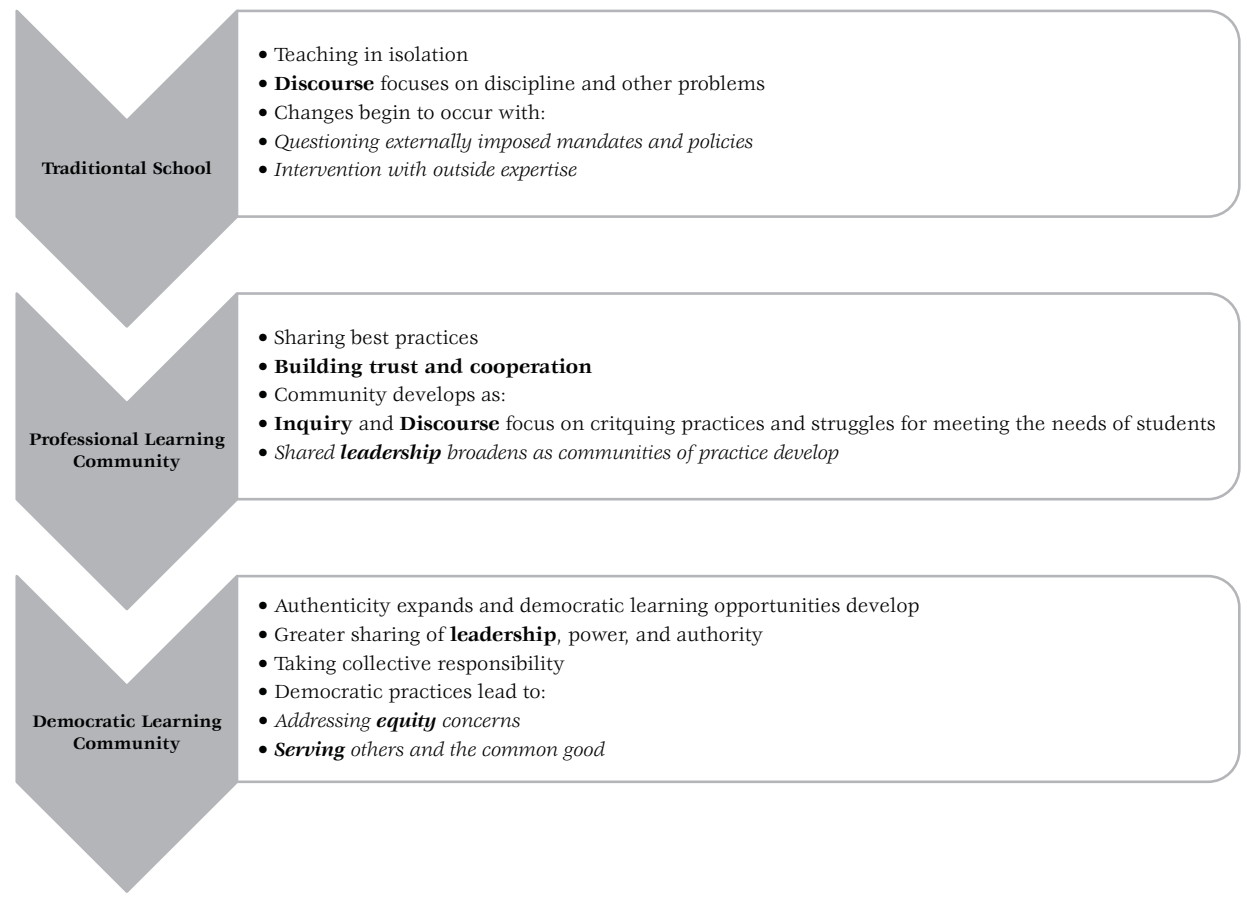

the work of most high school teachers is a private enterprise and their success is viewed as based on individual teacher quality. The leader determines what is shared and when it is shared. Elmore (2000) suggests that school institutions responded to progressive mandates through assuming the lack of teacher professionalism, establishing administrative-heavy supervisory structures, and increasing the size of schools. These responses focus on the management of processes outside instruction, rather than providing structures for reflection on instruction. In traditional schools, inquiry and discourse focus on issues outside of teaching and learning and are filtered through the leader who serves to protect instruction, and classrooms are lacking in authentic experiences for students (Elmore, 2000).

\section{Professional Learning Communities}

Creating structures and practices, such as establishing trust, sharing and critiquing best practices, and sharing of decisions, moves traditional schools toward becoming PLCs. This process of change is often underestimated because leaders do not grasp the need to differentiate based on teachers' skills and knowledge involved in changing a school's capacity (Darling-Hammond, 1997). Learning communities can be attained when schools' staffs are involved in collaborative systems with a shared purpose to increase student learning (Hord, 
1997; Joyce and Calhoun, 1996; Joyce et al., 1999; Louis et al., 1996; Newmann and Wehlage, 1995).

The process of change from a traditional high school to a learning community is a slow process in which numerous challenges must be overcome (Wells and Feun, 2007). The building leader needs to have a conceptual understanding of what it means to be a learning community, and also how to lead others through the change process (Wells and Feun, 2007). From their investigation of the principal's role in a learning community, Morrisey et al. (1999) suggest that principals start by establishing mechanisms through which they can obtain input regularly from staff. After having the knowledge and skills for participating through meaningful leadership roles, members of the community can assume those roles and continue their learning and often reflect on their learning and take actions accordingly.

Technology integration processes can be advantageous in contributing to the development of a collaborative culture in professional learning community development (Burns, 2002, Dexter et al., 2002, Riel and Fulton, 2001; Williams, 2006). When teachers collaboratively plan lessons and share ideas about integrating technology, similar changes in their classroom practices begin to occur (Becker and Riel, 2000). The increase in technology use in our society calls for schools to integrate technology into the learning process. A reciprocal relationship exists between technology integration and development of characteristics of a professional learning community (Atkinson et al., 2008). Through technology integration nurtured within a learning community, teachers become focused on continuous growth, and systemic changes within the school are produced (Williams et al., 2008).

\section{Democratic Learning Community}

In a school with a democratic-oriented leader, the actions for professional learning can became the foundation for democratic processes. When schools move into sharing of authority, collective identities, communities of practice, and serving others, a more democratic learning community emerges (Cate et al., 2006). Establishing a democratic learning community, especially in a high school, requires knowledge intensivity for all actors in the system (DarlingHammond, 1997), but especially for the leader. Murphy (2002) proposes a three-tier model of school leadership that addresses these complex tasks through social justice, school improvement, and democratic community. He further explains their conceptualization through metaphors of moral steward, a leader with a strong sense of purpose that focuses on justice, community, and high-quality teaching and learning; educator, a leader who addresses the pedagogical grounding for a focus on learning for all of the school community; and, community builder, a leader who opens up communication lines among multiple stakeholders and nurtures an increase in meaningful involvement that focuses on the best interests of students. Stefkovich and Begley (2007) explain that the dispositions of principals in the interpretation of what is in the best 
interest of the student shapes the decision-making of democratic leaders. Lambert (2005) explains that these school leaders continually engage in reflective and self-critical analysis to pursue the building of leadership capacity. Spillane et al. (1999) advance the theory that democratic leaders involve shared leadership across the system in an interdependent web. Lappe and DuBois (1994) describe a living democracy as one with enabling relationships that expand power with a focus on the common good and opportunities to experience democracy through discourse, diversity and conflict, listening, judging and reflecting. These characteristics of democratic learning communities increase students' learning (Cate et al., 2006).

A democratic learning community depends on a proactive principal who encourages job-embedded learning, teacher leadership, and involvement in meaningful decisions (Cate et al., 2006; Huffma et al., 2001; Reitzug and O'Hair, 2002). According to Dewey (1927), an educated citizenry contributes to its advancement. Democratic schools not only teach about democracy, but also create conditions for democracy by promoting an open flow of ideas, having faith in people's capacity to resolve problems, allowing opportunities for critical reflection, and focusing on the greater good balanced with individual dignity (Apple and Beane, 1995).

Although leadership is shared in a democratic community, still the leader 'must have the skills, knowledge, and disposition to work collaboratively and foster democratic community' (Kochan and Reed, 2005: 78). Kochan and Reed (2005: 78) label these leaders 'transcendent', meaning 'they can transcend circumstances, traditions, and barriers to create democratic environments as a natural part of their leadership role'. Democratic schools leaders 'engage in building capacity rather than building empires' (Rusch, 1995: 18). 'Leadership in a democratic school is viewed as being embodied in acts that may come from anyone in the school community, including teachers, students, and parents' (Reitzug and O'Hair, 2002: 122).

\section{IDEALS as a Foundation for Democratic Learning Communities}

Schools move toward democracy by encouraging 'participation, communication, and cross-cultural cooperation' (Furman and Shields, 2003: 8). As teamwork is instituted, the emergence of communities of practice that nurture learning and generate new practices and knowledge through being shared both explicitly and tacitly, begin to focus on the needs of students, rather than the needs of adults (Cate, 2004). O'Hair et al. (2000) describe strategies through which leaders share decisions, face obstacles and adjust practices as they address issues of social justice, equity and learning for all students. They propose a framework for creating and maintaining democratic learning communities, known as the IDEALS-Inquiry, Discourse, Equity, Authenticity, Leadership and Service-that includes inquiring about practices, supporting discourse about learning, focusing on equity issues, making learning connections with the real world, sharing leadership and promoting service. 
Through inquiry, school community members critically study their instructional and school practices, bringing community members together to engage with them as partners in discourse about these needs and possible courses of action to address their needs (Glickman, 1993). From the voices and ideas of all stakeholders, issues of equity emerge to the forefront during the discourse and decision making. Equity is a pivotal component of a democratic community that 'embraces individual differences, multiple group identities, and a unifying political community all at once' (Parker, 1996: 117). Diversity is not only accepted in democratic learning communities, it is cherished (Apple and Beane, 1995; Veugelers and Zijlstra, 2005). With a focus on authentic teaching, learning, and assessment students engage in construction of new knowledge through conducting disciplined inquiry about topics with value beyond the school (Newmann and Wehlage, 1995). Lessons are relevant and require complex problem-solving or higher order thinking skills. Students may be involved in service learning or have an audience for their learning outside of their classroom or school. Sharing information, ideas, engaging in authentic practices, and learning through inquiry and discourse builds the leadership capacity of the members of the school community (Lambert, 1998, 2003). Serving the common good through this work and reciprocating with valued interaction and service expands the boundaries of the school community and reaches to issues of the greater community (Apple and Beane, 1995). Service is a key component of a democratic learning community that sets it apart from a PLC (Reitzug and O'Hair, 2002). Without such a component the ideals of democratic learning communities can seem to be 'all talk and no action' (O'Hair et al., 2000: 431). Democratic learning communities teach students 'to learn, to serve, to question, and to act' (Glickman, 2003: 318).

In a democratic learning community that focuses on the IDEALS, collegial groups of teachers share tasks, resources and practices in an interdependent extended learning community that focuses on the common good and actions for the best interest of students (O'Hair et al., 2000). This democratic learning community model is a basis of the IDEALS model for school renewal (O'Hair et al., 2005) and forms a foundation of the university-school network supported through a technology grant project investigated as a part of this study. Furthermore, the IDEALS serve as the theoretical framework for this study.

\section{Methodology}

The case study methodology is useful for studying meaning with a holistic view for describing the deeper understanding behind the processes (Merriam, 1998). Case study is a process of investigation (Creswell, 2003) and valuable in creating a deep understanding of particular people or situations in comprehensive ways (Patton, 1990). Merriam (1998) posits that researchers must artificially separate the phenomenon from the context, yet understand that the phenomenon is dependent of that context. The focus of this multi-case study is on democratic 
processes with school change as the phenomenon. The multi-case study methodology serves as a modus to illuminate democratic processes that change schools and address the needs of the students, not the needs of the adults in the system.

\section{Data Collection and Analysis}

The study is a five-school, multi-case study that includes three data sets: (1) documents, such as action plans from school leaders, files and notebooks from the school-university network, grant proposals, surveys, reports and records; (2) semi-structured interviews, with both leaders and several teachers from each school; and (3) field notes, with school and classroom observations and professional development reports. Confidentiality is maintained for the schools, teachers and principals through the use of pseudonyms when discussing the qualitative results. Triangulation of data and member checks give school leaders the opportunity to review the transcripts and notes from their interviews and observations. The researchers are a part of the context. Thus, the researchers strive to bracket the data for objectivity. Data were reviewed independently by the researchers. The interviews serve as the primary source of data, with the field notes and documents used to support the interview data. The researchers compile and review the three sets of data from each case separately. Each researcher identifies examples of the IDEALS and then these examples are compiled, compared, and discussed. From these data, the researchers develop the multi-case study.

This multi-case study is descriptive in nature with the democratic learning community model, known as the IDEALS, as the foundation for analysis. This study investigates both insights of individual cases as well as compares the insights across the five cases (Merriam, 1998).

\section{The Cases}

The five purposefully selected high schools in this study serve Grade 9-12 students, but vary in size, residential area and socioeconomic status of the students. These US high schools are located in a Midwest state. Table 1 shows demographic information for the high schools studied.

Table 1 shows how the school size and demographics vary. The two suburban high schools have 2082 students and 126 teachers and 1822 students with 113 teachers, while the rural high school has 126 students with 23 teachers. The range in poverty is from 19\% free and reduced lunch students in the rural community to $53 \%$ free and reduced lunch students at the rural town, while the non-white population in the rural community is $10 \%$, with $46 \%$ non-white in the rural city.

The study includes these five high schools: High School (HS) Apple; HS Bartlett Pear; HS Cherry; HS Dogwood; and HS Magnolia. The study began in 2004 and ended in 2006 (see Table 2). Each of the five high school principals have participated in a 75-hour leadership development professional development 
Table 1 Demographic data from high school study sites

\begin{tabular}{lcclll}
\hline School & $\begin{array}{l}\text { Number of } \\
\text { students }\end{array}$ & $\begin{array}{l}\text { Number of } \\
\text { teachers }\end{array}$ & $\begin{array}{l}\text { Residential } \\
\text { area }\end{array}$ & Poverty (\%) & Minority (\%) \\
\hline High school 1: Apple & 832 & 48 & Rural city & 48 & 46 \\
High school 2: Bartlett Pear & 330 & 23 & $\begin{array}{l}\text { Rural } \\
\text { community }\end{array}$ & 19 & 10 \\
High school 3: Cherry & 312 & 32 & Rural town & 53 & 27 \\
High school 4: Dogwood & 1,822 & 113 & Suburban & 27 & 23 \\
High school 5: Magnolia & 2,082 & 126 & Suburban & 22 & 19 \\
\hline
\end{tabular}

Source: School report cards retrieved from http://www.schoolreportcard.org/.

program provided as a part of the university-school network originally through the Bill and Melinda Gates Foundation, and maintained through a state trust. In this program, school leaders receive a laptop computer and they engage in collaborative networking for the purpose of facilitating systemic school changes based on the IDEALS framework to improve student achievement. Four of the high school leaders in the study receive the PLC/technology grant. The school technology grant focuses on the development of a professional learning community using technology integration to increase student achievement. The grant also requires that schools select a learning team, with representative members of the school community, to build leadership capacity for change through implementation of their goals. Two of the high school leaders receive a United States Department of Education grant for smaller learning communities (SLC), which focuses on establishing structures for collaboration, student supports and learning community development. One of the schools receives both grants and implements the PLC/technology grant to facilitate student learning in a ninth grade, freshman core team as part of the smaller learning communities grant project. The implementation of the grant goals of each of these schools is supported through a university-school partnership. (Note: the university-school partnership is led by the researchers of this study. Bracketing, independent review and comparison of findings, and member review of interviews and notes provide some minimization of the bias of the researchers.) The grants provide resources and incentives for change with specific goals determined by each school team. The grants' resources include professional development, release time for teachers to work together in small groups, monitoring and accountability, and access to external expertise.

\section{Findings}

High schools are harder to change than other school levels because they are more organizationally and institutionally regimented and tend to be profoundly resistant to change (McLaughlin and Talbert, 2001). The pre-data show that 
three of the schools are traditional in governance structures, while the two larger schools have an established system of shared governance with the teacher leadership team meeting regularly as representatives of their department. One teacher describes her perception prior to the grant, and states, 'Often times as a teacher you just do your job in the classroom and think that nobody cares what you think and that the administration will just tell us what to do and make decisions for us.' Challenges that a principal of one of the larger school identifies are communication and collaboration. Similarly, the principal in one of the smaller rural schools identifies collaboration and staff development as challenges, mentioning that the school has multiple initiatives in progress at once. A teacher in another rural school notes that teacher isolation existed before the grant initiative.

As the first year of the study progresses, teachers begin to share their practices, share their learning, and share aspects of leadership. Most of the principals provide supportive conditions within the school, which impacts these shared processes. In one school, the lack of supportive conditions thwarts the sharing of practices, learning, and leadership. Table 2 shows the grant project involvement of each school and identifies which schools are categorized as traditional schools or professional learning communities at the beginning of the study and the category for each school at the end of the study.

Table 2 shows that three of the schools in the study begin as traditional schools, and two of these three schools transform into professional learning communities by 2006. Yet, one school stagnates at the traditional school category. Two schools begin with characteristics similar to professional learning communities and both progress towards becoming democratic learning communities. Varying levels of implementation of the IDEALS framework are exhibited by each of the schools and these seem to indicate whether the school moves towards becoming a learning community.

Table 2 Interventions (grant initiatives) and school structures at the beginning of the study (2004) end of the study (2006)

\begin{tabular}{|c|c|c|c|c|c|}
\hline & $\begin{array}{l}\text { Technology } \\
\text { grant }\end{array}$ & $\begin{array}{l}\text { Smaller } \\
\text { learning } \\
\text { community } \\
\text { grant }\end{array}$ & $\begin{array}{l}\text { Traditional } \\
\text { school } \\
\text { structures }\end{array}$ & $\begin{array}{l}\text { PLC } \\
\text { structures }\end{array}$ & $\begin{array}{l}\text { Democratic } \\
\text { LC structures }\end{array}$ \\
\hline HS 1: Apple & 2004 & & 2004 & 2006 & + \\
\hline HS 2: Bartlett Pear & 2004 & & 2004 & 2006 & + \\
\hline HS 3: Cherry & 2004 & & 2004 & & \\
\hline HS 4: Dogwood & 2004 & 2004 & & 2004 & 2006 \\
\hline HS 5: Magnolia & & 2004 & & 2004 & 2006 \\
\hline
\end{tabular}

Note: $\mathrm{A}+$ indicates that processes were in their initial phase. 
Table 3 IDEALS implementation in study sites

\begin{tabular}{llllll}
\hline $\begin{array}{l}\text { IDEALS } \\
\text { implementation }\end{array}$ & HS 1: & HS 2: & HS 3: & HS 4: \\
Apple & Bartlett Pear & Cherry & Hogwood & Magnolia \\
\hline Inquiry & Yes & Yes & No & Yes & Yes \\
Discourse & Yes & Yes & No & Yes & Yes \\
Equity & Some & Some & No & Yes & Yes \\
Authenticity & Some & Some & No & Yes & Yes \\
Leadership & Yes & Yes & No & Yes & Yes \\
Service & Some & Yes & No & Yes & Yes \\
\hline
\end{tabular}

\section{Inquiry}

In four of the five high schools, the principals establish multiple means for gathering stakeholder input. These range from surveys, meetings, committees, core teams and departments. Several of the schools focus on sharing their school's data and using these data to inquire into their school and classroom practices. One principal remarks, 'We collect data for everything we do. In a meeting earlier this week, my teacher leadership team gathered data from a needs assessment .... She continues to explain that her school has used a shared leadership team to develop the technology grant. In one of the schools a retired mathematics teacher organizes, analyzes, graphs and explains their school's data, which enhances the staff's understanding of the data. While at Cherry high school, the principal admits that he has provided limited opportunities for the teachers to meet and is trying to implement seven initiatives simultaneously. His teachers state that they lack commitment to the grant and feel overwhelmed with the multiple initiatives for which they are responsible.

For the schools involved in the grant that focuses on developing technologyenriched learning communities, administrators and teachers emphasize that technology has become a powerful tool to enhance inquiry and the use of data. One teacher states that their school is 'extensively using data to drive decisions to modify and improve instructional strategies and more teacher collaboration through the team meetings as well as interdepartmentally'. Some teachers admit their initial reluctance to change, but as they begin to inquire together about technology integration processes, the support of the principal and learning team convinces them to proceed. In fact, a teacher shares, 'It [technology] encourages the development of the teachers to become learners with the students.'

\section{Discourse}

In four of the five high schools, discourse begins to center around teaching and learning, with administrators supporting the time for the learning team to plan and work with other teachers. One teacher shares that the professional development sessions 'were a pinnacle of sharing information and learning together'. Several of the principals provide common planning times for team meetings. 
These meeting times allow teachers to inquire about and have discourse concerning their practices. Another administrator also provides opportunities for team meetings, even arranging for student programs to allow teachers time to plan together.

In the technology grant schools, many of the leaders and teachers discuss how they share resources and ideas as well as how technology enhances the sharing. They are able to share what they are learning and producing via email and school servers. One teacher emphasizes, 'Collaboration has increased because we can also share practices via email . . . we communicate with each other back and forth and are able to discuss teaching strategies.' Each of the principals share that effective communication to all stakeholders is key to their progress. 'We can't just say that we should collaborate, but as principals we have to put it into practice and get everyone involved. Then you're not just this school ... you're actually a good, productive community of learners.' She continues, 'Technology integration is a great place for teachers to start with focused dialogue. They are working ... to support each other and share and learn together.'

At four of the five schools, venues for both formal and informal discourse are embedded into school practices. One of the schools establishes a parent advisory council and the principal and council members present together about their organization at state conferences. The administrator of the fifth school, who admittedly does not involve stakeholders or establish supportive structures for discourse, explains, 'We're not as far as we need to be, and I don't have anything in place to set this expectation formally. Our parents tend to have blue-collar jobs and don't have time or knowledge to offer. We're the experts, and we think that parents should step back, listen to us and let us do our job as the professional educators.'

\section{Equity}

Equity is addressed at varying levels at the high schools. One school principal stresses that technology engages and motivates students and that she has seen increases in attendance and decreases in discipline problems in classrooms that are incorporating more authentic teaching and learning. She reflects that technology was the hook and that all kids benefited from more authentic instruction, 'but for some of my at-risk kids, it's the magic potion that engages them in the learning'. Survey data for one of the schools show a significant increase in making important decisions based on doing what is best for student learning. When reflecting on what has made a difference, a teacher shares, 'freshmen teams have really helped us identify and help at-risk kids'. This school begins to consider the perspective of the student and the needs of the student, instead of blaming the student or outside factors as many traditional schools do.

A review of student organizations in schools demonstrates a difference of offerings in the two larger high schools from the smaller schools. Both suburban 
schools have student organizations that promote awareness of different cultures and groups such as Black or African American students, Gay and Lesbian Alliances and other ethnic groups that included Native American, Chinese or Latino. While the smaller schools provide fewer student organizations, HS Cherry lists the fewest.

\section{Authenticity}

Authenticity in the classroom includes student construction of knowledge, engagement in deep inquiry around a concept, collaboration among students, and value beyond school through connections to the real world. Teachers begin to experiment with student collaboration first. One principal shares that the technology grant changes her school stating, 'I have seen dramatic changes in the classrooms and how teachers are interacting with the students.' One teacher explains, 'the extra layer of interactivity that technology brings as an instruction tool changes the way the students perceive information forever. Students transfer their knowledge among the content areas and... make connections'. Another principal emphasizes the changes brought about by the technology and smaller learning community initiatives, sharing that teachers are 'providing authentic experiences for their students that enhance interdisciplinary connections, problem solving and critical thinking'. A teacher shares how she has begun to take risks towards authentic teaching as she includes essential questions and group tasks. The hands-on experiences where students have an opportunity to actively participate in the lesson involves them in their own learning rather than being passive participants. 'At first it's scary, but once you get into it, you get excited about a new way of teaching that involves students more.' Caring teachers plan together to integrate innovative techniques and begin to see how they are making a difference for student learning.

For some of the 'old-school' teachers, instructional practices transform from traditional lecture style to providing problem-based and authentic experiences for students. The teachers' role in the classroom changes from knowledge-giver to knowledge-facilitator. As teachers become more comfortable, not experts, with the use of technology; they are more willing to take risks and offer opportunities for their students. The increased knowledge and new teaching strategies foster empowerment and reflection for teachers and is mirrored by active experiences that empower and engage students in producing their own learning and creating authentic products. In both SLC schools, teachers work collaboratively to create and teach relevant problem-based classroom lessons. A teacher shares what is making a difference as, 'Multiple strategies to involve student learning; shared value system and goals; implementation common to all teachers; complex thinking and multiple exposures to all curriculum activities.' Another teacher reflects on changes in the classroom stating, 'Student learning increases when they are able to become accountable to themselves, rather than to the teacher.' One school invites students to join teachers in the 
curriculum planning for advisory classes for the upcoming year. Cherry high school teachers continue to use worksheets and texts as their primary teaching tools.

\section{Leadership}

Four of the five schools extensively involve the leadership team in school-wide decision-making. One principal shares, 'I learned to step back and give power to them. They were more aggressive than I would have been ..... In fact, 'the team members gain confidence and competency ... Through a collaborative approach, we received support from central office and the school board in our decisions.' Teachers emphasize that school staffs learn more from each other in small groups with students' involvement and assistance than in large group workshops. 'The students caught the wave of excitement ... for total school involvement. Another principal reflects that his team leaders have learned so much about leadership and comments, 'It was new and scary . . they have done an exceptional job in leading their team groups and accepting the teacher leader role.' He continues, 'It was much easier for team leaders to sell the vision and get ownership from their peers than if I would have done it in a top-down autocratic manner. A shared vision guides school changes as one teacher reports, 'We have an overall vision of where we want to take our school, and dedicated people trying to reach those goals.' Stakeholder involvement is also being expanded and making a difference in several of the schools. 'Parents, students, teachers, counselors, and administrators work as a team to enhance student learning.'

In contrast, at the fifth school, the superintendent and central office staff develop the grant application, along with several other grant initiatives. The principal admits that he thought implementation would happen naturally and that he had established no processes for collaboration or professional development for the grant. He mentions that he has teachers who are unwilling to change and he admits that he struggles with how to prepare them for reform initiatives. The leadership team is a requirement of the grant, but they report feeling unsure of their responsibilities and overwhelmed with the multiple initiatives they are expected to implement.

\section{Service}

Each of the schools has student groups that engage in some form of service. The groups are more traditional at three of the high schools, with academic related organizations that conduct community service projects such as a Future Business Leaders of America organization that provides community service and a media club that provides school videos and works on the website. Larger service learning initiatives are active at the other schools. One school cooperates with the City-in-Schools and Adopt-a-School in community service initiatives, and one has students who collaborate with an elementary school on several service projects. 
Service is also provided by the school staff. One principal shares how she and teacher leaders identify students at the holidays who need assistance and provide food and gifts for their families. The SLC grant focuses on addressing the needs of all students. Thus, levels of intervention are established to support students who are having difficulty at both high schools involved in the grant. One of the schools implements a Link Crew concept in which senior student leaders mentor freshmen, while the other studies the possibility of a similar project. One teacher shares, 'The services available are making the greatest difference for our students' learning. We are teachers to all students. I have never felt that my students didn't belong to all the teachers here. A great system exists here for all of us.' Service learning is included in leadership classes and service learning is a part of a few core and elective courses at these schools.

\section{Discussion}

Both grant awards include a budget for professional development of teachers, collaborative norms, and a focus on impacting students. Yet, why are some grant implementations more effective than others? Could the differences rest with the dispositions and practices of the principal? If so, what are the dispositions and practices that lead to democratic learning communities that expand the boundaries?

Three of the schools are traditional schools when the grants are initiated, while two are progressing towards becoming a PLC. When the grants are awarded and the goals of the grants are established, two of the traditional schools and the two PLC schools involve and embrace teacher leadership teams. Supportive conditions are established that allow inquiry and discourse through teacher leadership teams that progress to implement grant goals. Inquiry, discourse, and shared leadership are the initiating strategies that create the impetus for a shared vision and shared implementation of grant goals. These processes occur through formal structures, such as professional development, team meetings, and department meetings, as well as through informal sharing, such as mentoring, peer-support, and email. With the foundation of inquiry and discourse into teaching practices, four of the five schools initiate authentic teaching and learning practices. Equity issues are topics of conversation, yet it is not until the foundational IDEALS has been established that these issues are addressed.

Each school has teachers at differing levels and with differing needs which increases the difficulty level of the change process as proposed by DarlingHammond (1997), and by expanding teacher leadership the schools are able to address these differing needs. The exception is found at HS Cherry in which teacher leadership is lacking. The building leader does not have a vision for how a learning community can assist the change process, nor did he know how to lead the change process, principle qualities which are identified as critical to making the change happen (Wells and Feun, 2007). Instead, he blames 
teachers, saying they are resistant to change, and blames the system, in that too many initiatives exist. In contrast, the other principals of HS Apple and HS Bartlett Pear involve the staff in the implementation phase of the grant and establish mechanisms through which input regularly is gathered from staff, a key to the development of a learning community (Morrisey et al., 1999).

Four of the principals begin to move their schools to a more democratic community through their actions as a moral steward, educator, and community builder (Murphy, 2002). For example, HS Dogwood and HS Magnolia principals provide professional development on innovative teaching and learning practices. The schools expand their boundaries for learning by engaging in conferences, site visits, and meetings through a university-school partnership, its network of schools, and other outside expertise. Through the network of schools, these schools gain knowledge and ideas about how other schools are addressing challenges. With the exception of HS Cherry, teachers from these schools inquire about the practices of others and engage in dialogue within and across their own boundaries. However, HS Cherry is represented in network meetings, gatherings, and conferences by district personnel, rather than by the principal or teachers.

In four of the five schools, student groups exist to support the diverse groups of students. These student groups work towards social justice. HS Apple and HS Bartlett Pear, provide additional planning times for teachers to share and prepare high-quality learning lessons for students. These four principals likewise begin to expand the school community boundaries, soliciting input and ideas from parents and community members. These leaders work collaboratively to foster democratic community (Kochan and Reed, 2005), providing opportunities and support for others to develop their own leadership capacity.

As leadership capacity is built, teachers begin to reflect on their roles and deepen their learning towards more democratic processes (Cate et al., 2006). As teachers collaborate as teams with shared understandings and shared purposes, they develop communities of practice, sharing knowledge, revealing tacit knowledge, and generating new knowledge. The focus of these communities of practice moves from that of the needs of adults, to the needs of the students. They begin to frame their decisions based on the best interest of the students. To varying degrees, these schools involve students in the experience of democracy, and developing student leadership. For example, at HS Dogwood, students are mentoring other students with adult facilitators and Dogwood students are working side-by-side with teachers to develop a student advisory curriculum.

As schools move from traditional organizations to professional learning communities to democratic learning communities, their boundaries are extended. First, as leaders open up their practices to be more inclusive, teachers begin to share their practices with each other. As teachers begin to collaborate about their teaching, they provide additional opportunities for students to share while they learn. As practices within the school begin to open up, the school 
begins to include those outside the school in meaningful ways. Diverse ideas and positions are respected and the school interacts as a partner in the greater community. The university-school partnership and the accompanying grants provide funding to support and encourage this transformation.

\section{Conclusion}

Advocates have called for transforming schools into more democratic systems (Furman and Starratt, 2002; Glickman, 2003; Gross and Shapiro, 2005; Murphy, 2002; Woods, 2005). However, there is little empirically based evidence of how democratic learning communities are established or the role of the leader in the process, especially in high schools. This study illuminates some of the challenges and strategies that facilitate or impede the process of creating more democratic schools that expand the boundaries of inquiry and discourse to include a broader range of community stakeholders and that respect and embrace issues of equity.

This multi-case study of five high schools suggests a pathway of change from traditional school structures to professional learning communities to democratic learning communities based on the level of implementation of the IDEALS. Establishing informal and formal structures that create opportunities for inquiry and discourse as well as providing support for shared leadership are the first steps towards establishing a learning community. School leaders who frame the inquiry and discourse around solutions, rather than problems facilitate the development of group ownership and empowerment. Through meetings in small groups and identification of learning teams which focus on solutions, teachers develop leadership skills. On the other hand, if these team sessions raise issues without solutions, they may stagnate and cause members to feel powerless. With these structures and supports in place, classroom practices are shared and teachers become learner-centered, rather than teacher-centered, allowing authenticity to become a focus. As the process builds, teachers expand their views and consider how students learn as they plan their lessons and begin to experiment with student collaboration, deeper inquiry, and allow students to construct their own knowledge. From authenticity processes in teaching and learning, service learning and ethos become a possibility and issues of equity emerge. Equity issues begin to be illuminated in those schools that review and study extensively their data. In these schools, the culture and perspective of students and stakeholders is embraced and the boundaries of the school are expanded and become more inclusive.

In smaller schools, establishing structures for Inquiry and Discourse create formidable challenges due to the multiple assignments of teachers and the difficulty of securing substitutes. At the same time, smaller schools tend to have more flexibility in their day-to-day scheduling so that leaders who understand the need for collaboration, become creative in establishing these processes. The need for leaders to understand the concept of democracy and for them to be 
willing to risk expecting some new structures and strategies facilitates the movement of their schools towards becoming a democracy. Democracy in practice is a complex process. There is not one best way or even one pathway to establish the conditions through which to arrive at democratic learning communities. In fact, the two suburban high schools approach implementation differently, but both progress in democratic processes to meet their grant goals. Yet, both begin with inquiry, discourse, and shared leadership, which act as a foundation for implementing authenticity, then equity and service.

One of the high schools remains a traditional school with a leader who lacks the understanding of what it meant to be a learning community, as described by Wells and Feun (2007). The teachers at HS Cherry remain isolated and focused on barriers to change. This inward focus thwarts their growth. Two of the high schools demonstrate characteristics of a learning community, with teachers accepting leadership roles and responsibilities. In these schools, the classroom boundaries are expanded by sharing of best practices within their school and with other schools. Based on a foundation of built trust, these school communities are sharing leadership and critiquing their own practices. Through these processes, both move towards school improvement and build community, as described by Murphy (2002). Faculty members at the two suburban high schools work together to develop communities of practice (Printy, 2004) and begin to focus decisions on the best interest of students (Stefkovich and Begley, 2007). These schools begin to extend democratic practices across boundaries and include more community members. These schools are focusing on collective concerns of collective responsibility for student learning and equity, as they move towards becoming a democratic learning community, as depicted in Figure 1.

As schools move along the continuum from traditional schools to professional learning communities and on to democratic learning communities, they extend their traditional boundaries. School leaders and teachers become competent in the use of new collaborative structures for sharing best practices and leadership as well as critiquing struggles and norms. Isolation and traditional schooling practices diminish. They analyze the needs of others and expand the boundaries of the school by considering student, parental, and then community needs. As professional learning communities develop, opportunities for student voice and expressions of student diversity within the school arise. In moving beyond PLC to democratic community, school members share power, authority and critical decisions; examine and act upon issues of equity; and consider serving others both within and outside the school. Providing democratic schools sounds simple in theory, yet this investigation demonstrates that, in practice, implementing democratic processes requires time, a level of understanding, networking and external support, and purposeful actions of school leaders as they progress through the continuum of change.

Being a democratic school is not a static state a school attains. Rather, it is a journey of educators who teach and work for democracy in their schools and 
communities. It often begins with a single step and involves a set of shared ideals to which the school strives-ideals reflected in the school's vision and everyday practices. Taking the first step involves creating structures to facilitate the sharing of best practices and may lead to the second step, the development of trust, which may in turn lead to additional steps. While no road map exists, the democratic IDEALS provide a framework through which to expand the traditional school boundaries and make honorable the quest.

\section{References}

Apple, M.W. and Beane, J.A., eds (1995) Democratic schools. Alexandria, VA: Association for Supervision and Curriculum Development.

Atkinson, L.C., O'Hair, M.J., O'Hair, H.D. and Williams, L.A. (March-May, 2008) 'Developing and Sustaining Schools as Technology Enriched Learning Organizations', I-manager's Journal on School Educational Technology 3(4): 17-33.

Brady, P. (2008) 'Working Towards a Model of Secondary School Culture', Canadian Journal of Educational Administration and Policy, 73. Available at: https://www.umanitoba.ca/publications/cjeap/articles/brady.html. Accessed 20 December 2008.

Becker, H.J. and Riel, M. (2000) Teacher Professional Engagement and ConstructivistCompatible Computer Use. Teaching, Learning, and Computing: 1998 National Survey: Report \#7. Center for Research on Information Technology and Organizations University of California, Irvine and University of Minnesota.

Burns, M. (2002) 'From Compliance to Commitment: Technology as a Catalyst for Communities of Learning', Phi Delta Kappan 84(4): 295-302.

Cate, J.M. (2004) Evolution of a High-Achieving School: Building Community through Learning, Leading, and Practices. University of Oklahoma: ProQuest.

Cate, J.M., Vaughn, C.A. and O'Hair, M.J. (2006) 'A Seventeen-Year Case Study of an Elementary School's Journey from Traditional to Learning Community to Democratic School', Journal of School Leadership 16(1): 86-111.

Creswell, J. (2003) Research Design: Qualitative, Quantitative, and Mixed Methods Approaches, 2nd edn. Thousand Oaks, CA: SAGE.

Darling-Hammond, L. (1997) The Right to Learn: A Blueprint for Creating Schools that Work. San Francisco, CA: Jossey-Bass.

Dewey, J. (1916) Democracy and Education. New York: The Macmillan Company.

Dewey, J. (1927) The Public and its Problems. New York: Capricorn.

Dexter, S., Seashore, K.R. and Anderson, R.E. (2002) 'Contributions of Professional Community to Exemplary Use of ICT', Journal of Computer Assisted Learning (18) 489-97.

Elmore, R.F. (2000) Building a New Structure for School Leadership. Washington, DC: The Albert Shanker Institute. Available at: http://www.shankerinstitute.org/Downloads/ building.pdf. Accessed 15 October 2003.

Furman, G.C. and Shields, C.M. (2003) 'How can Educational Leaders Promote and Support Social Justice and Democratic Community in Schools?'. Paper presented at the Annual Meeting of the American Educational Research Association, Chicago, IL.

Furman, G.C. and Starratt, R.J. (2002) 'Leadership for Democratic Community in Schools', in J. Murphy (ed.) The Educational Leadership Challenge: Redefining Leadership for the 21st Century. One Hundred-First Yearbook of the National Society for the Study of Education, pp. 105-33. Chicago, IL: National Society for the Study of Education. 
Glickman, C.D. (1993) Renewing America's Schools: A Guide for School Based Action. San Francisco, CA: Jossey-Bass.

Glickman, C.D. (1998) Revolutionizing America's Schools. San Francisco, CA: Jossey-Bass.

Glickman, C.D. (2003) Holding Sacred Ground: Essays on Leadership, Courage, and Endurance in our Schools. San Francisco, CA: Jossey-Bass.

Goodlad, J.I. and McMannon, T.J., eds (1997) The Public Purpose of Education and Schooling. San Francisco, CA: Jossey-Bass.

Green, J.M. (1999) Deep Democracy: Community, Diversity, and Transformation. Lanham, MD: Rowman \& Littlefield.

Gross, S.J. and Shapiro, J.P. (2005) Our New Era Requires a New DEEL: Towards Democratic Ethical Educational Leadership. pp. 1-4. UCEA Review, Fall.

Hargreaves, A. and Goodson, I. (2006) 'Educational Change Over Time? The Sustainability and Nonsustainability of Three Decades of Secondary School Change and Continuity', Educational Administration Quarterly 42(1): 3-41.

Hord, S. (1997) Professional Learning Communities: Communities of Continuous Inquiry and Improvement. Austin, TX: Southwest Educational Development Laboratory.

Huffman, J.B., Hipp, K.A., Pankake, A.M. and Moller, G. (2001) 'Professional Learning Communities: Leadership, Purposeful Decision Making, and Job-Embedded Staff Development', Journal of School Leadership 11(5): 448-63.

Joyce, B. and Calhoun, E. (eds) (1996) 'Learning Experiences in School Renewal: An Exploration of Five Successful Programs', Eugene, OR: ERIC Clearinghouse on Educational Management. (ED 401 600).

Joyce, B., Calhoun, E. and Hopkins, D. (1999) The New Structure of School Improvement: Inquiring Schools and Achieving Students. Buckingham: Open University Press.

Kochan, F.K. and Reed. C.J. (2005) 'Collaborative Leadership, Community Building, and Democracy in Public Education', in F.W. English (ed.) The SAGE Handbook of Educational Leadership: Advances in Theory, Research, and Practice, pp. 68-84. Thousand Oaks, CA: SAGE.

Lambert, L. (1998) Building Leadership Capacity in Schools. Alexandria, VA: Association for Supervision and Curriculum Development.

Lambert, L. (2003) Leadership Capacity for Lasting School Improvement. Alexandria, VA: Association for Supervision and Curriculum Development.

Lambert, L. (February 2005) 'Leadership for Lasting Reform', Educational Leadership 62: 5.

Lappe, F.M. and DuBois, P.M. (1994) The Quickening of America: Rebuilding our Nation, Remaking our Lives. San Francisco, CA: Jossey-Bass.

Lee, V.E. and Smith, J.B. (1996) 'Collective Responsibility for Learning and its Effects on Gains in Achievement for Early Secondary School Students', American Journal of Education 104: 109-46.

Louis, K.S., Marks, H.M. and Kruse, S. (1996) 'Teachers' Professional Community In Restructuring Schools', American Educational Research Journal 33: 757-98.

McLaughlin, M. and Talbert, J. (2001) Professional Communities and the Work of High School Teaching. Chicago, IL: University of Chicago Press.

Meier, D. (2002) In Schools we Trust: Creating Communities of Learning in an Era of Testing and Standardization. Boston, MA: Beacon Press.

Merriam, S. (1998) Qualitative Research and Case Study Applications in Education. San Francisco, CA: Jossey-Bass.

Morrisey, M., Cowan, D., Leo, T. and Blair, L. (August 1999) 'Renewing Teachers, Reforming Schools through Professional Learning Communities', SEDLetter XI, 8-11.

Murphy, J. (2002) 'Reculturing the Profession of Educational Leadership: New Blueprints', Educational Administration Quarterly 38: 176-91. 
Newmann, F.M. and Wehlage, G.G. (1995) Successful School Restructuring: A Report to the Public and Educators. University of Wisconsin, Madison, WI: Center on Organizational and Restructuring of School, Wisconsin Center for Education Renewal.

O'Hair, M.J., McLaughlin, H.J. and Reitzug, U.C. (2000) Foundations of Democratic Education. Orlando, FL: Harcourt.

O'Hair, M.J., Reitzug, U.C., Cate, J., Averso, R., Atkinson, L., Gentry, D., Garn, G. and Jean-Marie, G. (2005) 'Networking for Professional Learning Communities: SchoolUniversity-Community Partnerships Enhance Student Achievement', in W. Veugelers and M.J. O'Hair (eds) Network Learning for Educational Change, pp. 72-97. Maidenhead: Open University Press.

Parker, W.C. (1996) "Advanced" Ideas about Democracy: Toward a Pluralist Conception of Citizen Education [Electronic version]', Teachers College Record 98(1): 104-25.

Patton, M.Q. (1990) Qualitative Evaluation and Research Methods, 2nd edn. Newbury Park, CA: SAGE.

Printy, S.M. (2004) 'The Professional Impact of Communities of Practice', UCEA Review XLVI(1): 20-23.

Reitzug, U.C. and O'Hair, M.J. (2002) 'Tensions and Struggles in Moving Toward a Democratic School Community', in G.C. Furman (ed.) School as Community, pp. 119-41. Albany, NY: State University of New York Press.

Riel, M. and Fulton, K. (March 2001) 'The Role of Technology in Supporting Learning Communities', Phi Delta Kappan 82(7): 518-23.

Rusch, E.A. (1995) 'Leadership in Evolving Democratic School Communities'. A Paper presented at the Annual Meeting of the American Educational Research Association. San Francisco, CA. (ERIC Document Reproduction Service No. ED 392 117.) Schmoker, M. (1999) Results: The Key to Continuous School Improvement, 2nd edn. Alexandria, VA: Association for Supervision and Curriculum and Development. Spillane, J.P., Halverson, R. and Diamond, J.B. (1999) Toward a Theory of Leadership Practice: A Distributed Perspective. Evanston, IL: Northwestern University, Institute of Policy Research. Available at: http://www.letas.org/PDF/DLS_ipr_paper.doc. Accessed 4 April 2003.

Stefkovich, J. and Begley, P.T. (2007) 'Ethical School Leadership', Educational Management Administration \& Leadership 35(2):205-24.

Veugelers, W. and Zijlstra, H. (2005) 'Keeping School Networks Fluid: Networks in Dialogue with Educational Change', in W. Veugelers and M.J. O'Hair (eds) Network Learning for Educational Change, pp. 33-51. Maidenhead: Open University Press. Wells, C. and Feun, L. (2007) 'Implementation of Learning Community Principles: A Study of Six High Schools', NASSP Bulletin 91: 141-60.

Williams, L.A. (2006) 'The Influence of Technology Integration on High School Collaboration through the Development of a Professional Learning Community: A Mixed Methods Study', Dissertations Abstract International 67(04), AAT 3214722.

Williams, L.A., Atkinson, L.C., Cate, J.M. and O'Hair, M.J. (2008) 'Mutually Supportive Relationships between Learning Community Development and Technology Integration: The Impact on School Practices and Student Achievement', Theory into Practice 47(4): 294-302.

Woods, P.A. (2005) Democratic Leadership in Education. London: Paul Chapman Educational Publishing. 


\section{Biographical Notes}

LESLie a. Williams, PhD, University of Oklahoma, is a research associate professor in the Department of Educational Leadership and Policy Studies and Associate Director for Research at the K20 Center for Educational and Community Renewal at the University of Oklahoma. Dr Williams has published numerous research articles and scholarly chapters on educational reform, learning community development, professional development, building leadership capacity to sustain systemic school improvement, and the integration of technology in teaching and learning processes to improve student achievement. She has been a Co-PI (Co-Primary Investigator) for over US\$27 million in grants supporting K12 school improvement in Oklahoma. Dr Williams has been an educator for nearly 20 years, serving as a Grade 6-12 grade mathematics teacher, middle school principal, district mathematics curriculum director, and university professor.

JEAN MCGREGOR CATE, PhD, has been a US public school educator for over 30 years who served as a secondary science teacher, principal and district curriculum director. She has supervised principals, led administrative workshops for school improvement, curriculum alignment, walk throughs, leadership and supervision and taught graduatelevel educational administration courses. Currently, she serves as an associate director of the K20 Center for Educational and Community Renewal at the University of Oklahoma, directing university partnerships and leadership development projects and teaching educational leadership courses.

MARY JOHN O'HAIR, EdD, University of Oklahoma, is vice provost for School and Community Partnerships at the University of Oklahoma and Professor of Educational Leadership. She is the founding director of OU's K20 Center for Educational and Community Renewal, a statewide, interdisciplinary research and development center that connects the university with over 500 schools and communities across Oklahoma. During her tenure, the K20 Center has innovated learning through democratic IDEALS (inquiry, discourse, equity, authenticity, leadership, and service) and a four-phased model for systemic change. Receiving over US\$40 million in external funding from public and private sources, K20 is impacting student learning and engagement throughout Oklahoma. She has published numerous articles and books on systemic innovation, organizational learning, and school-university-community partnerships. Her most recent book published by Open University Press is entitled Network Learning for Educational Change (2005; coedited with Wiel Veugelers).

\section{Correspondence to:}

MARY JOHN O'HAIR, School and Community Partnerships, University of Oklahoma, Norman, OK 73072, USA. [email: mjohair@ou.edu] 